\title{
Usage Intention of Qr Mobile Payment System Among Millennials in Malaysia
}

Mohd Uzairi Ahmad Hajazi, Seng Sou Chan, Siti Aisyah Ya’kob, Fadilah Siali, Hamrila Abdul Latip

To Link this Article: http://dx.doi.org/10.6007/IJARBSS/v11-i1/8494

DOI:10.6007/IJARBSS/v11-i1/8494

Received: 10 December 2020, Revised: 03 January 2021, Accepted: 15 January 2021

Published Online: 28 January 2021

In-Text Citation: (Hajazi et al., 2021)

To Cite this Article: Hajazi, M. U. A., Chan, S. S., Ya'kob, S. A., Siali, F., \& Abdul Latip, H. (2021). Usage Intention of Qr Mobile Payment System Among Millennials in Malaysia. International Journal of Academic Research in Business and Social Sciences, 11(1), 645-661.

\section{Copyright: (c) 2021 The Author(s)}

Published by Human Resource Management Academic Research Society (www.hrmars.com)

This article is published under the Creative Commons Attribution (CC BY 4.0) license. Anyone may reproduce, distribute, translate and create derivative works of this article (for both commercial and non-commercial purposes), subject to full attribution to the original publication and authors. The full terms of this license may be seen at: $\underline{\text { http://creativecommons.org/licences/by/4.0/legalcode }}$

\section{Vol. 11, No. 1, 2021, Pg. 645 - 661}

Full Terms \& Conditions of access and use can be found at http://hrmars.com/index.php/pages/detail/publication-ethics 


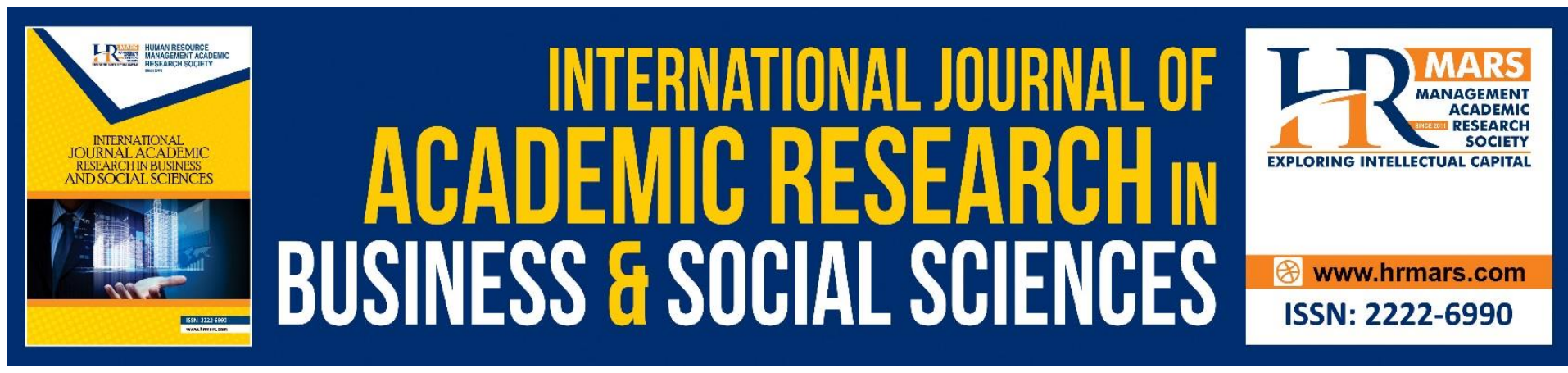

\title{
Usage Intention of Qr Mobile Payment System Among Millennials in Malaysia
}

\section{Mohd Uzairi Ahmad Hajazi ${ }^{1}$, Seng Sou Chan ${ }^{1}$, Siti Aisyah Ya'kob $^{1,2}$, Fadilah Siali' ${ }^{1,3}$, Hamrila Abdul Latip ${ }^{1}$}

${ }^{1}$ Faculty of Economics and Business, Universiti Malaysia Sarawak, Malaysia, ${ }^{2}$ Azman Hashim International Business School, Universiti Teknologi Malaysia, Malaysia, ${ }^{3}$ School of

Management, Universiti Sains Malaysia, Malaysia.

Email: ahmuzairi@unimas.my

\begin{abstract}
In line with the growth of smartphone and internet penetration, there is a growing trend of cashless payment made via smartphone, or mobile payment system, especially among millennials in Malaysia. Despite its advantages - which includes convenience, fast, and efficient among others - the adoption of the mobile payment system is still low. In this research, the usage intention of QR mobile payment system is observed through seven dimensions, namely perceived usefulness, perceived ease of use, perceived security, perceived compatibility, social influence, rewards, and personal innovativeness. 300 set of questionnaires was distributed among millennials as target respondents, and the data was analyzed using Pearson Correlation Analysis. The result showed that except social influence, all six other dimensions showed a significant and positive relationship with usage intention of QR mobile payment system.
\end{abstract}

Keywords: Mobile Payment, Usage Intention, Qr Code, Business Operation, Technology Adoption.

\section{Introduction}

The rapid growth of smartphones' technology has changed our daily life. Initially, early smartphones were marketed predominantly to enterprise clients and business professionals, therefore other than core phone functions such as text messaging and voice call, it also featured basic mobile computing capabilities such as web browsing, map and multimedia functionality to support the need of the users. However, in less than two decades, the technological advancement has made the device becoming more powerful with a wide range of computing capabilities and advanced features. Finger-operated touchscreen has replaced traditional QWERTY keypads, further expanding its user-friendliness and ease-of-use, thus boosted the adoption of the device in the mass market. With its advanced functions, smartphones are no longer considered as luxury item, but a must-have personal device for communication, access to information, business activities, commerce, leisure and entertainment. 
With the growing trends of smartphone penetration, as well as the increased use of mobile devices in e-commerce, it has led to the emergence of mobile payment tools (Aydin and Burnaz, 2016). According to Dahlberg et al. (2008), mobile payments are "payments for goods, services, and bills with a mobile device such as mobile phone such as mobile phone, smartphones, or personal digital assistant (PDA) by taking advantage of wireless and other communication technologies." In addition, payments via smartphone is also known as "Mobile Proximity Payment," or in short - MPP (PricewaterhouseCoopers, 2016).

Mobile payment is considered as one of major alternative payment methods and it is used in various application and situations. Predominantly used in online shops, brick-and-mortar retailers nowadays has also been accepting mobile payment as an alternative to cash. In addition to retail industry, service providers such as in healthcare industry (hospitals, clinics, pharmacies etc.), tourism industry (airlines, travel agents, hotels etc.), entertainment industry (cinemas, theme parks etc.), telecommunication industry (prepaid, bills etc.) and transportation industry (trains, taxi, bus etc.) among others, have also been employing mobile payment system as part of their business operation. Not only limited for private businesses, public organizations, government agencies and not-for-profit organizations have also adopting the system. Payment for local council assessment bills, university's tuition fee, 'zakat' (almsgiving practiced by Islamic religion), donations, public parking fee and parking fines are among services that have started to accept mobile payment system (Boost, n.d.; SarawakPay, n.d.)

In line with the growth of smartphone usage, the usage of mobile payment has also been growing. According to PricewaterhouseCoopers (2016), the transaction volume using mobile payment globally was valued at USD4.6 billion in 2014 and expected to exceed USD300 billion by 2020 . In Malaysia, transaction volume via mobile payment had increased 20 -fold from below two million transactions in 2017 to over 34 million transactions in 2018 (Chong, 2019). However, albeit the number is growing, the use of mobile payment is still low compared to other type of payment transaction, even for e-commerce transaction. According to JP Morgan (2019), approximately only seven percent of total e-commerce transaction in Malaysia is done via mobile payment. Bank transfer and card (debit or credit) are still dominating the payment transaction in e-commerce, at $46 \%$ and $29 \%$ respectively (JP Morgan, 2019).

There are several reason on the low adoption rate of mobile payment. Among them is the concerns of people about the exposure to fraud, data theft, and stealing, especially when it comes to financial information (Mei and Aun, 2019). In fact, according to Lee (2009), security and risk perception are among the reasons that prohibits the intention to use a new mobile payment system. Other than security, potential users' perception on the benefits of using such system also could hamper the adoption of mobile payment system. It is true that there are a lot of benefits can be associated from using the mobile payment system. For example, adding more money into your mobile wallet is significantly easy and faster compared to having to drive to nearest automatic teller machines and queuing up to withdraw your money. Not only that, transferring your money or receiving money from others is easy and can be done in no time at all. However, despite all these benefits, doubts on its usefulness continued to exist (Mei and Aun, 2019). In addition to these, several other factors could also influence the adoption of mobile payment, such as peer influence (Koenig-Lewis et al., 2015); ease of use (Mun et al., 2017); and compatibility to user's existing behavior, value or need (Aydin and Burnaz, 2016) among others.

There are many type of mobile payments used in the market, depending on the technology used by the service providers. The most commonly used is Near Field Communication, or NFC 
(PricewaterhouseCoopers, 2016). Using NFC, contactless payment can be made only when customers' device such as smartphone, is placed close to merchant's contactless payment reader - approximately within four inches (FIS, 2019). Other than NFC, Person-to-Person (P2P) technology allows transaction between two parties by secure accounts with in a same service provider (PricewaterhouseCoopers, 2016). Alongside these two technologies, there is a Quick Response (QR) code that allows payment to be made by either 1) scanning a merchant's QR code using smartphone, or 2) by displaying a QR code in the smartphone to be scanned by merchant (PricewaterhouseCoopers, 2016). Each of these technologies has its own merit and disadvantages. However, there is a lack of studies comparing different technologies of mobile payments (de Luna et al., 2019). In studying the usage intention of mobile payment, it is therefore more appropriate if the study focuses only into a specific payment system. In this sense, this study chooses to focus only on the QR mobile payment system, as most mobile payment systems that are commonly used in Malaysia are using this technology.

Based on the above, this paper aim to investigate the relationship between several dimensions - namely perceived usefulness, perceived ease of use, perceived security, perceived compatibility, social influence, rewards, and personal innovativeness, with the usage intention of QR mobile payment system among millennial in Malaysia.

\section{Literature Review}

There is a considerable amount of research done for understanding factors that might lead to the adoption of new technologies. From theoretical perceptive, among theories that is widely used is Theory of Reasoned Action (TRA) by Fishbien and Ajzen (1975). According to TRA, one's behavior is determined by the intention to perform such behavior, and the intention itself is a function of two determinants, which are attitude and subjective norms. (Ajzen \& Fishbein, 1980; Fishbein \& Ajzen, 1975). From TRA, another theory called Theory of Planned Behavior (TPB), was developed. As an extension of TRA, in TPB, another dimension, which is perceived behavioral control dimension, is added to the model (Ajzen, 1991). From this stream of social psychology research, Davis (1989) introduced Technology Acceptance Model (TAM), which was also developed based on TRA, but to represent the antecedents of technology use (Yousafzai et al., 2010). The TAM is similar to TRA, in the sense that TAM hypothesizes that a person's acceptance of a technology is determined by the intention to use of that technology, and the intention to use it determined by attitude towards the use of the technology. Attitude, in turn, is determined by two beliefs which are perceived usefulness and perceived ease of use (Yousafzai et al., 2010).

With regards to the usage intention of mobile payment, based on TAM, several researchers of previous studies have proposed additional constructs to their research model. For instance, a study about the intention to use mobile payment services by Liu and Tai (2016) also includes factors such as mobility, convenience, and compatibility among other in their research model. Meanwhile, Aydin and Burnaz (2016) in their study about the adoption of mobile payment system proposed several other dimensions other than perceived usefulness and perceived ease of use. For example, personal innovativeness, perceived security, and rewards among others. Based on past studies about the usage intention of mobile payment system, this present study incorporated seven constructs that may have relationship with the usage intention. 


\section{Perceived Usefulness}

The concept of perceived usefulness is developed by Davis (1989) in his model of Technology Acceptance Model (TAM). According to Davis (1989), perceived usefulness is "the degree to which a person believes that using a particular system would enhance his or her performance". It can be defined as one's feeling about how a new system can potentially benefit him/her and help them improve (Mathwick et al., 2001). From these two definitions, it can be said that if a potential user think that the new system will provide certain benefits, the individual may develop intention to actually try and use the system. Previous studies such as from Mun et al. (2017), and Wong and Hiew (2005) founds that the usage intention of mobile commerce is affected by perceived usefulness. In addition, perceived usefulness also is found to be among key factors in explaining usage intention in different contexts (Kim and Lee, 2011; Leng et al., 2011). Therefore, we hypothesize that:

$\mathrm{H}_{1}$ : There is a significant and positive relationship between perceived usefulness with usage intention of QR mobile payment system.

\section{Perceived Ease of Use}

One of concerning factors of a consumer in adopting a new system, in this case the QR mobile payment system, is how easy the system is for them to use. According to Davis (1985), perceived ease of use is "the degree to which an individual believes that using a particular system would be free of physical and mental effort." This factor is considered as one of the largest influencers on the acceptance of new technology (Davis et al., 1992; Moore and Benbasat, 1991). Should an individual think that the new system is easy to use, and it is effortless to understand, learn and use the system, he or she will find the system is worth trying and adopt. Similarly, an individual might refuse to try and adopt a new system if he or she found or think that the system is difficult to use, tedious and complex. With regards to mobile payment system, a research by Mun et al. (2017) found that there is a strong relationship between perceived ease of use and the intention of use of mobile payment. Based on the previous studies mention above, therefore, we hypothesize that:

$\mathrm{H}_{2}$ : There is a significant and positive relationship between perceived ease of use with usage intention of QR mobile payment system.

\section{Perceived Security}

Another important factor that might related to the adoption of QR mobile payment system is perceived security. According to Tsiakis and Sthephanides (2005), security is a set of procedures and programs to verify the information source. Within the context of mobile payment meanwhile, security can be categorized into three areas, which are systems security, transaction, and legal (Teah et al., 2013). According to Mallat (2007), lack of perceived security is one the factors that lead to low rate of mobile payment usage. Nowadays, there are various technologies used in providing high-level of security in mobile transaction such as cryptography (Crowe \& Tavilla, 2012). Although the security feature of mobile payment system is on par with other payment system such credit card (Aydin and Burnaz, 2016), it is the concerns on the perceived security of mobile payment systems create a barrier in the adoption, not the actual security, (Kim et al., 2010; Ovum, 2012). Fear of online cyber theft, 
fraud, passive confidentiality are the barriers that consumer resists to use the mobile wallet payment (Yang et al, 2012). To confirm the relationship between perceived security with the usage intention of QR mobile payment, the following hypothesis is therefore proposed.

$\mathrm{H}_{3}$ : There is a significant and positive relationship between perceived security with usage intention of QR mobile payment system.

\section{Perceived Compatibility}

In his book, Rogers (2003) defined perceived compatibility as "the degree to which an innovation is perceived as being consistent with the existing values, needs, and past experiences of potential adopter." Schierz et al. (2010) meanwhile explained that "perceived compatibility encompasses the reconcilability of an innovation with existing values, behavioral patterns, and experiences." From these two definitions, it can be said that one's decision to adopt new technology, or in this study's context - QR mobile payment system will be influenced by whether the technology is able to meet the adopter's lifestyle, behavior or needs. For instance, does QR mobile payment system fits into his or her shopping habit, or can the system integrate into his or her lifestyle? Previous researches have observed that perceived compatibility are found to be an important element on technology acceptance (Moore and Benbasat, 1991; Tornatzky and Klein; 1982). Similar findings also can be found in the context of mobile payment (Aydin and Burnaz, 2016; Schierz et al., 2010). It is therefore we expect that individual who thinks that the system is able to match his or her existing needs, lifestyle or behavior will generate an interest in adopting QR mobile payment system.

$\mathrm{H}_{4}$ : There is a significant and positive relationship between perceived compatibility with usage intention of QR mobile payment system.

\section{Social Influence}

The influence of family members, friends, peers or any person important to an individual cannot be ignored in shaping the individual's action or belief, and this is also applicable in the context of technology adoption. This is especially true when the technology is still in the infancy or introductory stage, in which they are only few adopters (Mun et al., 2017). Therefore, the lack of publicly available and reliable information about the innovation might influence individuals to get the information from people they trust. Prior studies provide evidence, which suggesting that social influence is one of the important factor that influence the adoption of technology in general (Leng et al., 2011; Venkatesh and Davis, 2000), and mobile commerce specifically (Toh et al., 2009; Khalifa and Cheng, 2002). In line with these findings, therefore, we hypothesize that:

$\mathrm{H}_{5}$ : There is a significant and positive relationship between social influence with usage intention of QR mobile payment system.

\section{Rewards}

From marketing perspectives, Kim and Han (2014) observed that when the advertisement includes benefits, consumers' concentration on the advertisement is increased. Extrinsic rewards in the form of tangible benefits such as coupons, rebate, sample gift etc. can motivate consumers (Aydin and Burnaz, 2016). According to Evans (2014), reward system through loyalty point is a driven factor that can motivate consumer to use the mobile payment system. 
In addition, Points (2016) in their report also pointed out that "a key way to encourage continued adoption and long-term use is to build loyalty into mobile wallet." In the same report, they also pointed out that" $94.4 \%$ of consumers surveyed would use a mobile wallet more frequently if they could earn or redeem points and miles with every purchase." Based on these argument, the following hypothesis is proposed.

$\mathrm{H}_{6}$ : There is a significant and positive relationship between rewards with usage intention of QR mobile payment system.

\section{Personal Innovativeness}

There are differing definition use to define innovativeness, depending on the disciplines (Amoroso and Lim, 2015). Individuals who are early to adopt an innovation can be identified as innovative (Rogers, 2003), and Agarwal and Prasad (1998) meanwhile in their study defined personal innovativeness in the domain of information technology as "the willingness of an individual to try out any new information technology." Compared to those are not, individuals who are innovative are more ready to accept and adopt new technologies (Aydin and Burnaz, 2016). Previous studies have test the effect of personal innovativeness on the adoption behavior of innovations in IT system (Agarwal and Prasad, 2011), mobile service (Zarmpou et al., 2012) and mobile wallet (Aydin and Burnaz, 2016). In addition to that, Sulaiman et al. (2007) in their study about mobile banking adoption in Malaysia has found that individuals with high level of innovativeness tend to adopt the system, while in Singapore, a study by Yang (2005) also reported a positive influence of innovativeness on mobile commerce adoption in the country. Based on the above literature, the following hypothesis is proposed.

$\mathrm{H}_{7}$ : There is a significant and positive relationship between personal innovativeness with usage intention of $Q R$ mobile payment system.

\section{Data Collection and Sampling}

The target population for this study is millennials born between 1980 and 1999 living in Kota Samarahan, a city in the state of Sarawak, Malaysia. This group of individuals are chosen as they are the key age demographic for online commerce (Smith, 2015), therefore are most probably being exposed to and have experience in using QR mobile payment system. Nonprobability method is implemented for the sampling with convenience sampling is one of the sampling techniques being applied in this study. In addition, snowball sampling technique, in which a respondent was asked to identify other individual who met the criteria required by the research (Biernacki \& Waldorf, 1981) is also being used in this study. These two techniques are adopted with the interest of practicality and expediency.

The questionnaire used in this study consists of three sections. In the first section, respondent's demographic profile and four questions related to their experience in using $Q R$ mobile payments were asked. In the second section, respondents were asked about factors influencing the usage of QR mobile payment system - namely perceived usefulness, perceived ease of use, perceived security, perceived compatibility, social influence, rewards, and personal innovativeness. Meanwhile, in the third section, questions related to their intention of using QR mobile payment system were asked. In both second and third section, respondents were asked to indicate the extent of their agreement with the statements of each construct on a five-point Likert scale with 1 being "strongly disagree" and 5 as "strongly agree". In addition, all measurement items used in this questionnaire are adopted from 
previous literatures - namely from Venkatesh \& Davis (2000); Mun et al. (2017); Liu \& Tai (2016); Aydin \& Burnaz (2016); Kumar, Lall \& Mane (2017); Anthony (2014); Amoroso \& Lim (2015); Lwoga \& Lwoga (2017); Mallat (2007) and Phuah, K. T. et al. (2018). This selfadministered questionnaire is distributed to 300 target respondents via online.

\section{Findings and Discussion}

\section{Demographics Profile of Respondent}

Based on the data collected for this study, out of the overall 300 respondents, 174 respondents (58\%) are male while 126 respondents (42\%) are female. Respondents within the age range between 19 years old to 23 years old make up the largest portion among the respondents with a total of 205 (68.3\%), followed by $24-28$ years old (27.3\%), $34-38$ years old $(2.3 \%)$ and $29-33$ years old (2.0\%). Most of them are student $(53.7 \%)$, while $22.7 \%$ of them are full-time employee. The remaining respondents are either working part-time (16.7), self-employed $(6.7 \%)$ or unemployed $(0.3 \%)$. In terms of educational background, $61.3 \%$ of them are currently holder of Bachelor's degree, and $20.7 \%$ of them are Diploma holder or equivalent. Meanwhile, $14.3 \%$ of the respondents are SPM holder or equivalent, $3.3 \%$ are Master's degree holder and $0.3 \%$ other qualification. The detailed profile of respondent is presented in Table 1.

Table 1: Demographic Profile of Respondent

\begin{tabular}{|c|c|c|c|}
\hline Demographic Profile & Category & Frequency & $\begin{array}{c}\text { Percentage } \\
\text { (\%) }\end{array}$ \\
\hline Gender & $\begin{array}{l}\text { Male } \\
\text { Female }\end{array}$ & $\begin{array}{l}174 \\
126\end{array}$ & $\begin{array}{l}58 \\
42\end{array}$ \\
\hline Age (years old) & $\begin{array}{l}19-23 \\
24-28 \\
29-33 \\
34-38\end{array}$ & $\begin{array}{c}205 \\
82 \\
6 \\
7\end{array}$ & $\begin{array}{c}68.3 \\
27.3 \\
2.0 \\
2.3\end{array}$ \\
\hline Occupation & $\begin{array}{l}\text { Student } \\
\text { Full time employee } \\
\text { Part time employee } \\
\text { Unemployed } \\
\text { Self-employed }\end{array}$ & $\begin{array}{c}161 \\
68 \\
50 \\
1 \\
20\end{array}$ & $\begin{array}{c}53.7 \\
22.7 \\
16.7 \\
0.3 \\
6.7\end{array}$ \\
\hline Educational Background & $\begin{array}{l}\text { SPM (or equivalent) } \\
\text { STPM/Diploma/Pre-U (or } \\
\text { equivalent) } \\
\text { Bachelor's degree } \\
\text { Master's degree } \\
\text { Other }\end{array}$ & $\begin{array}{c}43 \\
62 \\
184 \\
10 \\
1\end{array}$ & $\begin{array}{c}14.3 \\
20.7 \\
61.3 \\
3.3 \\
0.3\end{array}$ \\
\hline
\end{tabular}

\section{Reliability Analysis}

In order to check the internal consistency (Cooper and Schindler, 2008; Zikmund et al., 2009) of each item in a study, as well as the accuracy and precision (Cooper and Schindler, 2008), 
reliability analysis is performed. Based on the Cronbach's Alpha, all variables used in this study are considered having an acceptable level of internal consistency and degree of reliability, as the value of the Cronbach's Alpha for all variables are greater than 0.7 (Sekaran, 2000; Zikmund et al., 2009). Table 2 below shows the result of the reliability test done for this study.

Table 2: Reliability Test

\begin{tabular}{|l|c|c|}
\hline Dimension & Number of Item & Cronbach's Alpha \\
\hline Perceived Usefulness & 6 & 0.895 \\
\hline Perceived Ease of Use & 5 & 0.879 \\
\hline Perceived Security & 5 & 0.865 \\
\hline Perceived Compatibility & 6 & 0.869 \\
\hline Social Influence & 5 & 0.706 \\
\hline Rewards & 5 & 0.893 \\
\hline Personal Innovativeness & 5 & 0.843 \\
\hline Usage Intention & 9 & 0.868 \\
\hline
\end{tabular}

\section{Descriptive Analysis}

Descriptive analysis was performed to identify respondents' usage experience of QR mobile payment system. From the Table 3 below, it is found that $68.3 \%$ of the respondents have been using or had used G-Pay, one of the most commonly used and established mobile payment application in Malaysia. M-Pay, a system provided by a leading financial institution in Malaysia, meanwhile rank second with $56.0 \%$, followed by TG-Pay (55\%), and B-Pay (48\%). GPay also rank first when the respondents were asked about the most frequently used payment system. $36 \%$ of them answer G-Pay for this question, followed by TG-Pay (19\%), M-Pay (18\%) and B-Pay (15\%). In addition, in responding to the question "I use QR mobile payment the most when I make payment for ...", 195 out of 300 respondents or $65 \%$ of them answered "Food \& beverage", followed by "Groceries" (14.3\%) and "Other" (10.3\%). Only three respondents, or one percent of total respondents has never used the system before. For the remaining $99 \%, 38.7 \%$ of them has been using the system for about one to six months, and $25.7 \%$ of them just started using the system less than a month. $34.7 \%$ of the respondents meanwhile identified themselves as an experienced user, having used the system for more than 6 months.

Table 3: Usage Experience

\begin{tabular}{|l|l|c|c|}
\hline Statement & Category & Frequency & $\begin{array}{c}\text { Percentage } \\
\text { (\%) }\end{array}$ \\
\hline $\begin{array}{l}\text { QR mobile payment system } \\
\text { that I use or have used }\end{array}$ & A-Pay & 13 & 4.3 \\
before. (Multiple answers & B-Pay & 144 & 48.0 \\
allowed) & F-Pay & 53 & 17.7 \\
& TG-Pay & 165 & 55.0 \\
& W-Pay & 64 & 21.3 \\
& M-Pay & 168 & 56.0 \\
& G-Pay & 205 & 68.3 \\
& S-Pay & 6 & 2.0 \\
\hline
\end{tabular}




\begin{tabular}{|l|l|c|c|}
\hline Statement & Category & Frequency & $\begin{array}{c}\text { Percentage } \\
\text { (\%) }\end{array}$ \\
\hline Frequently used QR mobile & A-Pay & 0 & 0 \\
payment system & B-Pay & 45 & 15.0 \\
& F-Pay & 7 & 2.3 \\
& TG-Pay & 57 & 19.0 \\
& W-Pay & 18 & 6.0 \\
& M-Pay & 54 & 18.0 \\
& G-Pay & 108 & 36.0 \\
& S-Pay & 0 & 0 \\
& Not using it frequently & 9 & 3.0 \\
& Other & 2 & 0.7 \\
& & & \\
\hline I use QR mobile payment the & Food and beverage & 195 & 65.0 \\
most when I make payment & Apparel & 13 & 4.3 \\
for & Groceries & 43 & 14.3 \\
& Petrol & 10 & 3.3 \\
& Not using it frequently & 8 & 2.7 \\
& Other & 31 & 10.3 \\
& & & \\
\hline Usage experience (duration) & Less than a month & 77 & 25.7 \\
& One to six months & 116 & 38.7 \\
& More than six months & 104 & 34.7 \\
& Not applicable & 3 & 1.0 \\
& & & \\
\hline
\end{tabular}

\section{Correlation Analysis}

In this study, correlation analysis is used in measuring the relationship between independent variables, which are perceived usefulness, perceived ease of use, perceived security, perceived compatibility, social influence, rewards, and personal innovativeness - with usage intention as dependent variable. All variables in the questionnaire are measured using interval scale, therefore the Pearson correlation coefficient is appropriate in examining the relationships (Sekaran \& Bougie, 2013). The strengths of correlation relationship between variables is referred to the rule of thumb provided by Hair et. al (2009), in which a very strong relationship is defined when coefficient ranging from 0.81 to $1.00,0.61$ to 0.80 is strong, moderate $(0.41$ to 0.60$)$, weak with low correlation $(0.21$ to 0.40$)$, and very weak to no relationship at all (0.00 to 0.20). Based on Pearson Correlation Analysis result in the Table 4 below, except for social influence $(r=0.15, p=0.799)$, all independent variables were found to be significantly and positively correlated with dependent variable. It also found that all independent variables (except for social influence) has weak positive relationship with usage intention, with perceived usefulness has the strongest relationship among all $(r=0.296, p=$ $0.000)$, followed by perceived security $(r=0.293, p=0.000)$, perceived ease of use $(r=0.244$, $p=0.000)$, perceived compatibility $(r=0.240, p=0.000)$, personal innovativeness $(r=0.156$, $p=0.007)$, and rewards $(r=0.142, p=0.014)$. 
INTERNATIONAL JOURNAL OF ACADEMIC RESEARCH IN BUSINESS AND SOCIAL SCIENCES

Vol. 11, No. 1, 2021, E-ISSN: 2222-6990 @ 2021 HRMARS

Table 4: Pearson Correlation Analysis

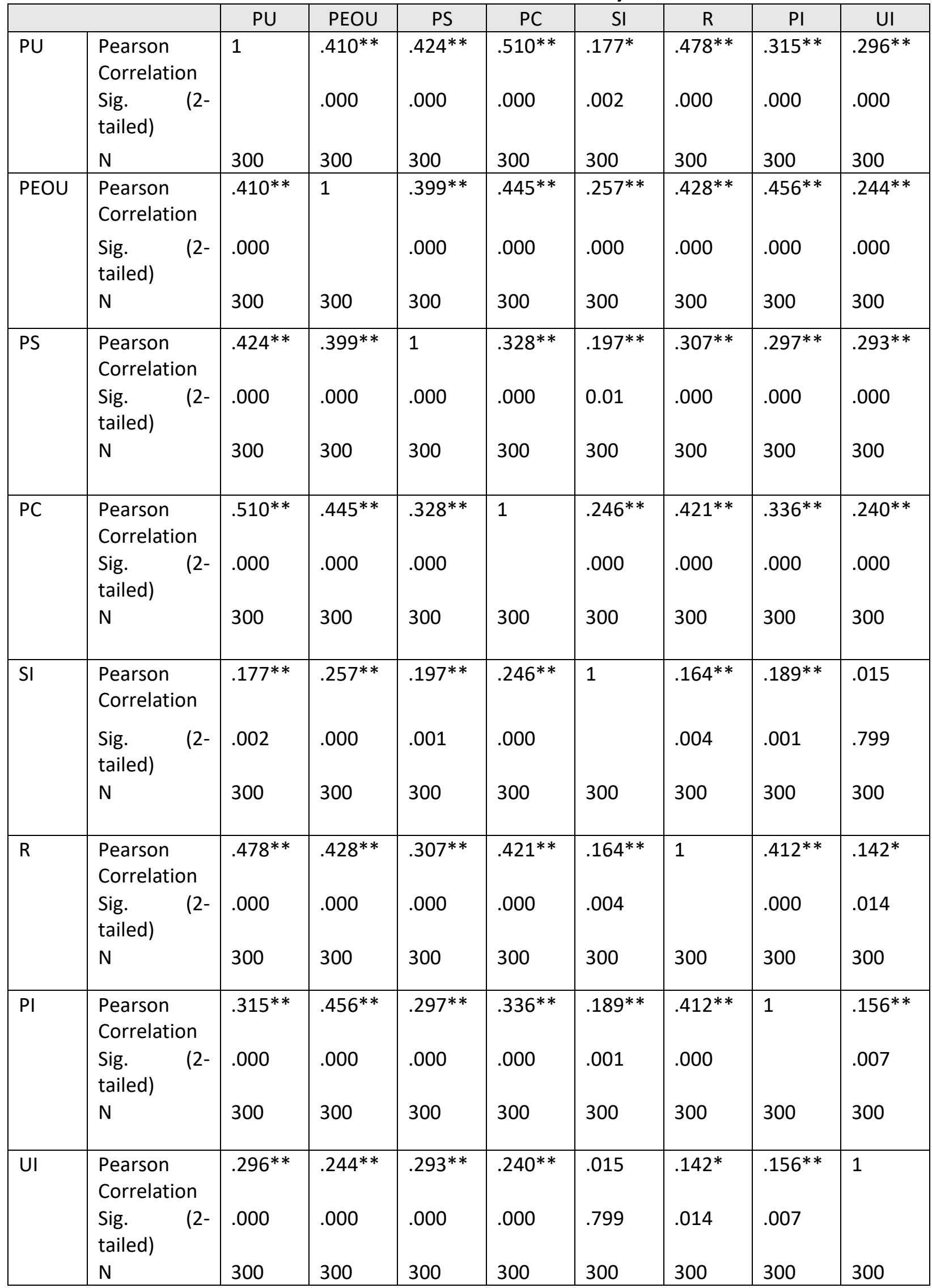


** Correlation is significant at the 0.01 level (2-tailed).

PU: Perceived usefulness, PEOU: Perceived Ease of Use, PS: Perceived Security, PC: Perceived Compatibility, SI: Social Influence, R: Rewards, PI: Personal Innovativeness, UI: Usage Intention.

\section{Hypothesis Testing}

Based on the result above, it can be concluded that except for Hypothesis 5, all other six hypotheses proposed for this study are supported (refer Table 5).

Table 5: Summary of Hypothesis

\begin{tabular}{|l|c|}
\hline Hypothesis & Findings \\
\hline $\begin{array}{l}\mathrm{H}_{1}: \text { There is a significant and positive relationship between perceived } \\
\text { usefulness with usage intention of QR mobile payment system. }\end{array}$ & Supported \\
\hline $\begin{array}{l}\mathrm{H}_{2}: \text { There is a significant and positive relationship between perceived } \\
\text { ease of use with usage intention of QR mobile payment system . }\end{array}$ & Supported \\
\hline $\begin{array}{l}\mathrm{H}_{3}: \text { There is a significant and positive relationship between perceived } \\
\text { security with usage intention of QR mobile payment system. }\end{array}$ & Supported \\
\hline $\begin{array}{l}\mathrm{H}_{4}: \text { There is a significant and positive relationship between perceived } \\
\text { compatibility with usage intention of QR mobile payment system. }\end{array}$ & Supported \\
\hline $\begin{array}{l}\mathrm{H}_{5}: \text { There is a significant and positive relationship between social } \\
\text { influence with usage intention of QR mobile payment system. }\end{array}$ & Not supported \\
\hline $\begin{array}{l}\mathrm{H}_{6}: \text { There is a significant and positive relationship between rewards } \\
\text { with usage intention of QR mobile payment system. }\end{array}$ & Supported \\
\hline $\begin{array}{l}\mathrm{H}_{7}: \text { There is a significant and positive relationship between personal } \\
\text { innovativeness with usage intention of QR mobile payment system }\end{array}$ & Supported \\
\hline
\end{tabular}

\section{Discussion}

With the exception of social influence, all other independent variables, namely - perceived usefulness, perceived ease of use, perceived security, perceived compatibility, rewards, and personal innovativeness - are found to be having a positive and significant relationship with the usage intention of QR mobile payment system. With regards to perceived usefulness, this result is consistent with previous research by Liu and Tai (2016) done in Vietnam. As mentioned above, previously, cashless transaction only can be made via credit card. However, as most people nowadays has smartphones, using a QR mobile payment system enables an individual to make cashless payment without having a credit card - especially when you are university's student or fresh graduate who just started a career. Adding money and making a payment via QR mobile payment system also is a significantly quicker and easier compared to using cash. The system provides a user with value and benefits in terms of minimizing time, efficiency as well as cost incurred to withdraw cash, therefore it might have explained why perceived usefulness has the strongest relationship with the usage intention of QR mobile payment system among other variables.

From the result, perceived ease of use also is found to be having a significant positive relationship with the usage intention of QR mobile payment system. This is consistent with the findings from studies done by Kumar et. al (2017), Cao et. al (2016), and Ntaukira et. al (2019). Individuals will be inclined to use QR mobile payment system only if they figure out that the system is not difficult to understand, learn and use. Therefore, in order to increase the usage of QR mobile payment system, the service provider must make sure their system is 
easy-to-use. For instance, the installation procedure must be effortless and easy to implement, and the system's user interface must be simple, easy-to-navigate, efficient, responsive and consistent. With regards to perceived security, from this study, it is found that this dimension too has a significant and positive relationship with usage intention. This is consistent with studies done by Kumar et. al (2018), and by Liu and Tai (2016). Even though there are many advantages and benefits that a user can get by using QR mobile payment system, if it is not safe, the consumer will not accept it as a replacement, nor as an alternative to the traditional type of payment transaction. Potential user must be assured by service provider that their personal and financial information as well as their privacy are safe and secure.

Another factor that was found to be significant and have a positive relationship with usage intention is perceived compatibility. This finding is accordance with a study by Aydin and Burnaz (2016), and Liu and Tai (2016). If the system is consistent with one's needs, value, and experience, an individual might be tempted to use the system. Only when consumers find the system suits their lifestyle or behavior, they are more willing to use and adopt the system. Therefore, a service provider must highlight and communicate to their potential users about the system's compatibility with their characteristics such as shopping behavior.

One important finding from this study is there is no significant relationship between social influence with usage intention. As the QR mobile payment system has been in the market for a few years now, and it is widely used especially among millennial, the influence from family members, friends or other individuals becoming less relevance in persuading them in using the system. A similar finding also has been reported in Aydin and Burnaz (2016). On the other hand, with regards to rewards, the same study has a contrary outcome from this study. In this study, rewards are found to have a positive and significant relationship with the usage intention. As there are many $Q R$ mobile payment system in the market nowadays, service providers tend to provide additional benefits in attracting potential users to use their service instead of competitors. These extra benefits normally come in the form of loyalty points, cashback, rebates and other forms of rewards. This might explain why rewards are found to have a relationship with the usage intention. Personal innovativeness is another dimension that is found to be significant and has a positive relationship with usage intention of $Q R$ mobile payment system. A similar finding can also be found in Lwoga and Lwoga (2017). As this study was focusing on millennial, this outcome is not surprising as millennial are tend to be more curious and open towards trying new things, especially when it involves smartphone technology.

\section{Conclusion and Recommendation}

Based on Pearson Correlation Analysis conducted in this study, the major finding of this study shows that social influence does not has a significant relationship with the usage intention of QR mobile payment system. In addition, the result of this study also indicates that the other six constructs, namely perceived usefulness, perceived ease of use, perceived security, perceived compatibility, rewards, and personal innovativeness are found to show a positive and significant relationship with the usage intention of QR mobile payment system. Based on these major findings, several recommendations are suggested. Firstly, as social influence is found to be not having a significant relationship with the usage intention, it is therefore appropriate for service providers to not rely solely on word-of-mouth in growing their customer base, especially among millennials. As most millennial are technology-savvy, the focus should be placed on improving service offering, which is our second recommendation. 
For instance, a service provider should improve and highlight the system's user-friendliness, safety and security features. Thirdly, service providers should also change their marketing communication to emphasize how their system suit the current lifestyle, behavior and values of their target markets, as well as bringing the attention of potential users to the additional rewards a user can get from the using their system such as cash rebate and discount.

This study's outcome may offer imperative understandings on the usage intention of the system among millennials especially in Kota Samarahan, Sarawak, but may not hold for other geographical areas. Therefore, among improvement that can be made to further understand the usage intention of QR mobile payment system is to include a broader geographic coverage. A comparative study between user and non-user, or between different demographic profiles such as age and gender could also be implemented to further understand how these factors might influence the usage of such payment system. In addition, a study specific to a certain application might be more useful in studying the usage intention of QR mobile payment system. For example, the intention to use the system for the payment of parking fee or parking notice might be influenced by different factors compared to using it for payment of goods in a retail shop. Future researchers are also to encourage to expand the sample size as higher number respondents would result in more accurate representation of the population.

\section{Acknowledgement}

This paper is supported by grant scheme F01/SpGS/1556/2017 by the Universiti Malaysia Sarawak (UNIMAS).

\section{Reference}

Agarwal, R., \& Prasad, J. (1998). A conceptual and operational definition of personal innovativeness in the domain of information technology. Information systems research, 9(2), 204-215.

Ajzen, I. (1991). The theory of planned behavior. Organizational behavior and human decision processes, No.50, pp. 179-211.

Ajzen, I., \& Fishbein, M. (1980). Understanding Attitudes and Predicting Social Behaviour, Englewood Cliffs, NJ: Prentice Hall PTR.

Amoroso, D. L., \& Lim, R. A. (2015). Exploring the personal innovativeness construct: the roles of ease of use, satisfaction and attitudes. Asia pacific journal of information systems, 25(4), 662-685.

Anthony, D., \& Mutalemwa, D. K. (2014). Factors influencing the Use of Mobile Payments in Tanzania: Insights from Zantel's Z-pesa services. Journal of Language, Technology \& Entrepreneurship in Africa, 5(2), 69-90.

Aydin, G., Bumaz, S. (2016). Adoption of Mobile Payment Systems: A Study on Mobile Wallets. Journal of Business, Economic and Finance, 5(1), 73-74.

Biernacki, P., \& Waldorf, D. (1981). Snowball sampling: Problems and techniques of chain referral sampling. Sociological Methods \& Research, 10(2), 141-163.

Boost. (n.d.). Boost Product \& Services. Retrieved from https://support.myboost.com.my/hc/en-us/sections/900000610506-Boost-ProductServices

Cao, T. K., Dang, P. L., \& Nguyen, H. A. (2016). Predicting consumer intention to use mobile payment services: Empirical evidence from Vietnam. International Journal of Marketing Studies, 8(1), 117-124. 
Chong, J. H. (2019). BNM: E-payment migration promising as mobile payment volume spikes. The Edge Markets. Retrieved from https://www.theedgemarkets.com/article/bnmepayment-migration-promising-mobile-payment-volume-spikes

Crowe, M., \& Tavilla, E. (2012). Mobile Phone Technology: "Smarter" Than We Thought. Federal Reserve Bank of Boston, 136-149.

Dahlberg, T., Mallat, N., Ondrus, J., \& Zmijewska, A. (2008). Past, present and future of mobile payments research: A literature review. Electronic commerce research and applications, 7(2), 165-181.

Davis, F. D. (1989). Perceived usefulness, perceived ease of use, and user acceptance of information technology. MIS Quarterly, Vol.13, no.3, pp. 319-340.

Davis, F. D., Bagozzi, R. P., \& Warshaw, P. R. (1992). Extrinsic and intrinsic motivation to use computers in the workplace. Journal of applied social psychology, 22(14), 1111-1132.

de Luna, I. R., Liébana-Cabanillas, F., Sánchez-Fernández, J., \& Muñoz-Leiva, F. (2019). Mobile payment is not all the same: The adoption of mobile payment systems depending on the technology applied. Technological Forecasting and Social Change, 146, 931-944.

Evans, M. (2014). Leveraging Consumer Loyalty to Drive Mobile Payments Adoption., Euromonitor International. Retrieved from https://www.pymnts.com/assets/Uploads/pdf/Leveraging-Consumer-Loyalty-toDrive-Mobile-Payments-Adoption.pdf

Fishbein, M., \& Ajzen, I. (1975). Belief, attitude, intention and behavior: an introduction to theory and research. Reading: Addison-Wesley.

FIS. (2019). 7 things to know about accepting NFC mobile payments. Retrieved from https://www.fisglobal.com/en/insights/merchant-solutions-worldpay/article/nfcpayment-acceptance-for-smbs

Hair J. F., Black, W. C., Babin, B. J., \& Anderson, R. E. (2009). Multivariate Data Analysis (Seventh Ed.).

Morgan, J. P. (2019). E-commerce Payments Trends: Malaysia. Retrieved from https://www.jpmorgan.com/merchant-services/insights/reports/malaysia

Khalifa, M., \& Shen, K. N. (2008). Explaining the adoption of transactional B2C mobile commerce. Journal of Enterprise Information Management. Vol. 21 No. 2, pp. 110-124.

Kim, C., Mirusmonov, M., \& Lee, I. (2010). An empirical examination of factors influencing the intention to use mobile payment. Computers in Human Behavior, 26(3), 310-322.

Kim, J., \& Lee, J. E. R. (2011). The Facebook paths to happiness: Effects of the number of Facebook friends and self-presentation on subjective well-being. CyberPsychology, behavior, and social networking, 14(6), 359-364.

Kim, Y. J., \& Han, J. (2014). Why smartphone advertising attracts customers: A model of Web advertising, flow, and personalization. Computers in Human Behavior, 33, 256-269.

Koenig-Lewis, N., Marquet, M., Palmer, A., \& Zhao, A. L. (2015). Enjoyment and social influence: predicting mobile payment adoption. The Service Industries Journal, 35(10), 537-554.

Kumar, K. S., Sivashanmugam, C., \& Venkataraman, A. (2018). Intention to use mobile wallet: Extension of TAM model. Journal of Electronic Systems, 8(1), 27-34.

Kumar, V. R., Lall, A., \& Mane, T. (2017). Extending the TAM model: Intention of management students to use mobile banking: Evidence from India. Global Business Review, 18(1), 238-249. 
Lee, M. C. (2009). Factors influencing the adoption of internet banking: An integration of TAM and TPB with perceived risk and perceived benefit. Electronic commerce research and applications, 8(3), 130-141.

Leng, G. S., Lada, S., Muhammad, M. Z., Ibrahim, A. A. H. A., \& Amboala, T. (2011). An exploration of social networking sites (SNS) adoption in Malaysia using technology acceptance model (TAM), theory of planned behavior (TPB) and intrinsic motivation. The Journal of Internet Banking and Commerce, 16(2), 1-27.

Liu, G. S., \& Tai, P. T. (2016). A study of factors affecting the intention to use mobile payment services in Vietnam. Economics, 4(6), 249-273.

Lwoga, E. T., \& Lwoga, N. B. (2017). User Acceptance of Mobile Payment: The Effects of UserCentric Security, System Characteristics and Gender. The Electronic Journal of Information Systems in Developing Countries, 81(1), 1-24.

Mallat, N. (2007). Exploring consumer adoption of mobile payments-A qualitative study. The Journal of Strategic Information Systems, 16(4), 413-432.

Mathwick, C., Malhotra, N. K., \& Rigdon, E. (2002). The effect of dynamic retail experiences on experiential perceptions of value: an Internet and catalog comparison. Journal of retailing, 78(1), 51-60.

Mei, Y. C., \& Aun, N. B. (2019). Factors Influencing Consumers' Perceived Usefulness of MWallet in Klang Valley, Malaysia. Review of Integrative Business and Economics Research, 8, 1-23.

Moore, G. C., \& Benbasat, I. (1991). Development of an instrument to measure the perceptions of adopting an information technology innovation. Information systems research, 2(3), 192-222.

Mun, Y. P., Khalid, H., \& Nadarajah, D. (2017). Millennials' perception on mobile payment services in Malaysia. Procedia Computer Science, 124, 397-404.

Ntaukira, J., Khomba, J. K., \& Maliwichi, P. (2019). Investigating Factors That Determine Continuous Intention Behaviour To Use Mobile Payment Services In Malawi (No. 2110). EasyChair.

Ovum. (2012), Digital Wallet Dynamics., pp. 1-12. Retrieved from http://www.mahindracomviva.com/wp-content/uploads/2015/02/MahindraComviva-Digital-Wallet-Whitepaper.pdf

Phuah, K. T., TingJL, J. L., \& Wong, K. K. S. (2018). Understanding customer intention to use mobile payment services in Nanjing, China. International Journal of Community Development and Management Studies, 2, 049-060.

Points. (2016). The State of Mobile Wallet Loyalty and Engagement in 2016. Retrieved from http://www.paymentscardsandmobile.com/wp-content/uploads/2016/10/The-Stateof-Mobile-Wallet-Loyalty-and-Engagement.pdf

PricewaterhouseCoopers. (2016) Mobile proximity payment: 5 things retailers should know. Retrieved from https://www.pwc.com/it/it/publications/assets/docs/mobileproximity.pdf

Rogers, E. M. (2003). Diffusion of Innovations. New York, USA: Free Press.

SarawakPay. (n.d.) Retrieved from https://www.facebook.com/sarawakpay.gov/

Schierz, P. G., Schilke, O., \& Wirtz, B. W. (2010). Understanding consumer acceptance of mobile payment services: An empirical analysis. Electronic commerce research and applications, 9(3), 209-216.

Sekaran, U., \& Bougie, R. (2013). Research methods for business: A skill building approach. John Wiley \& Sons. 
Smith, C. (2015). The surprising facts about who shops online and on mobile. Retrieved from https://www.businessinsider.com/the-surprising-demographics-of-who-shops-onlineand-on-mobile-2014-6/?IR=T

Sulaiman, A., Jaafar, N. I., \& Mohezar, S. (2007). An overview of mobile banking adoption among the urban community. International Journal of Mobile Communications, 5(2), 157-168.

Teoh, W. M. Y., Chong, S. C., Lin, B., \& Chua, J. W. (2013). Factors affecting consumers' perception of electronic payment: an empirical analysis. Internet Research.

Toh, T. W., Marthandan, G., Chong, A. Y., Keng-Boon Ooi, \& Arumugam, S. (2009). What drives malaysian m-commerce adoption? an empirical analysis. Industrial Management \& Data Systems, 109(3), 370-388. doi:http://dx.doi.org/10.1108/02635570910939399

Tornatzky, L. G., \& Klein, K. J. (1982). Innovation characteristics and innovation adoptionimplementation: A meta-analysis of findings. IEEE Transactions on engineering management, (1), 28-45.

Tsiakis, T., \& Sthephanides, G. (2005). The concept of security and trust in electronic payments. Computers \& Security, 24(1), 10-15.

Venkatesh, V., \& Davis, F. D. (2000). A theoretical extension of the technology acceptance model: Four longitudinal field studies. Management science, 46(2), 186-204.

Wong, C. C., \& Hiew, P. L. (2005). Correlations between factors affecting the diffusion of mobile entertainment in Malaysia. In Proceedings of the 7 th international conference on Electronic commerce (pp. 615-621).

Yang, K. C. (2005). Exploring factors affecting the adoption of mobile commerce in Singapore. Telematics and informatics, 22(3), 257-277.

Yang, S., Lu, Y., Gupta, S., Cao, Y., \& Zhang, R. (2012). Mobile payment services adoption across time: An empirical study of the effects of behavioral beliefs, social influences, and personal traits. Computers in Human Behavior, 28(1), 129-142.

Yousafzai, S. Y., Foxall, G. R., \& Pallister, J. G. (2010). Explaining internet banking behavior: theory of reasoned action, theory of planned behavior, or technology acceptance model?. Journal of applied social psychology, 40(5), 1172-1202.

Zarmpou, T., Saprikis, V., Markos, A., \& Vlachopoulou, M. (2012). Modeling users' acceptance of mobile services. Electronic Commerce Research, 12(2), 225-248. 